Zeszyty Naukowe Szkoły Głównej Gospodarstwa Wiejskiego w Warszawie Problemy Rolnictwa Światowego tom 17 (XXXII), zeszyt 1, 2017: 195-205

DOI: 10.22630/PRS.2017.17.1.18

Monika Szafrańska ${ }^{1}$

Uniwersytet Rolniczy im. H. Kołłątaja w Krakowie

\title{
Świadomość młodzieży akademickiej na temat rolnictwa
}

\section{The Awareness of Academic Youth on Agriculture}

\begin{abstract}
Synopsis. Celem pracy jest ocena poziomu świadomości rolniczej młodzieży akademickiej z woj. małopolskiego oraz określenie wybranych czynników determinujących ten poziom. Ich znajomość może stanowić podstawę działań różnych podmiotów, które przyczynią się do wzrostu świadomości rolniczej młodego pokolenia. Zasadniczym źródłem danych wykorzystanych do analizy i wnioskowania były informacje pierwotne uzyskane $\mathrm{z}$ badań własnych, przeprowadzonych metodą PAPI na grupie 436 studentów. Do pomiaru i oceny świadomości młodzieży na temat rolnictwa wykorzystano indeks świadomości rolniczej. Jak wynika z przeprowadzonych badań, większość respondentów nie rozumie roli rolnictwa, którą odgrywa ono w gospodarce, społeczeństwie i środowisku. Determinantami poziomu świadomości rolniczej w grupie studentów były płeć oraz miejsce zamieszkania.
\end{abstract}

Słowa kluczowe: świadomość rolnicza, młodzież akademicka, województwo małopolskie

\begin{abstract}
The aim of the work is to assess the level of agricultural awareness of academic youth and to pinpoint selected factors determining this the level. Being familiar with these determinants might serve as the basis for taking some actions by various entities which contribute to the increase in the agricultural awareness of the young generation. The main source of the data used for the analyses and applications was the primary information obtained from personal research. The research was done by using PAPI method on the group of 436 students. In order to measure and evaluate the youth awareness on agriculture the index of agricultural awareness was used. The findings of the studies indicate that the level of agricultural awareness of academic youth on the role in economy, society and environment is low. The determinants of agricultural awareness among students were gender and abode.
\end{abstract}

Key words: agricultural awareness, academic youth, Voivodship of Lesser Poland

\section{Wprowadzenie}

Podstawową funkcją rolnictwa jest produkcja gotowych artykułów żywnościowych oraz surowców do przerobu w przemyśle rolno-spożywczym. Surowce rolnicze, poza wykorzystaniem w przetwórstwie rolno-spożywczym na cele żywnościowe i paszowe, stosowane są także $\mathrm{w}$ innych gałęziach przemysłu, $\mathrm{m}$. in. w przemyśle farmaceutycznym, chemicznym, kosmetycznym oraz tekstylnym. Ekonomiczne i społeczne uzasadnienie maja także inne potencjalne rynki zbytu surowców rolnych, w tym energetyka (wytwarzanie energii z biomasy stałej, biogazu i biopaliw). Wymienione funkcje produkcyjne rolnictwa nie są jedyne. Rolnictwo jako integralna część gospodarki ma bardzo duży potencjał w realizowaniu różnorodnych funkcji pozaprodukcyjnych (Piwowar, 2014).

\footnotetext{
${ }^{1}$ dr inż., Uniwersytet Rolniczy w Krakowie, Al. Mickiewicza 21, 31-120 Kraków, e-mail: m.szafranska@ur.krakow.pl
} 
W literaturze przedmiotu istnieje wiele klasyfikacji pozakomercyjnych funkcji rolnictwa. Van Huylenbroeck i inni (2007) proponują podział tych funkcji na cztery grupy. Pierwsza grupa to funkcje zielone, obejmujące ochronę różnorodności biologicznej i poprawę obiegu materii i energii. Funkcje niebieskie związane są z gospodarką wodną (ochrona jakości wody, ochrona przeciwpowodziowa). Kolejna grupa to funkcje żółte, obejmujące utrzymanie żywotności obszarów wiejskich i tożsamości wsi. Z kolei na funkcje białe składają się działania związane $\mathrm{z}$ zapewnieniem bezpieczeństwa żywnościowego.

Gospodarka rolna ma zatem istotny wymiar nie tylko gospodarczy, ale także społeczny. Jak twierdzi S. Urban (2014), wiedza społeczeństwa na ten temat znajduje się na niskim poziomie. Szczególnie niepokojący jest fakt, że najniższym poziomem świadomości na temat roli rolnictwa w gospodarce, społeczeństwie i środowisku cechują się osoby młode (Kondratowicz-Pozorska, 2015).

Głównym celem niniejszej pracy jest ocena poziomu świadomości na temat rolnictwa młodzieży akademickiej oraz określenie wybranych czynników determinujących ten poziom. Ich znajomość może stanowić podstawę działań różnych podmiotów, które przyczynią się do wzrostu świadomości rolniczej młodego pokolenia.

\section{Istota świadomości rolniczej}

Po raz pierwszy termin świadomość rolnicza ( $\mathrm{z}$ ang. agricultural awareness, agricultural literacy) został użyty w 1988 roku przez National Research Council (NRC) w Stanach Zjednoczonych w odniesieniu do tworzenia programów nauczania na studiach wyższych. Organizacja ta wskazała na konieczność włączenia do programów studiów wiadomości o rolnictwie i żywieniu człowieka, aby każdy obywatel w przyszłości mógł dokonywać świadomych wyborów dotyczących m.in. diety (Williams, 1991). W literaturze przedmiotu znajdują się także inne określenia badanego zjawiska. M. J. Frick określił świadomość rolniczą jako wiedzę potrzebną każdemu obywatelowi, obejmującą podstawowe wiadomości z zakresu wytwarzania produktów roślinnych i zwierzęcych, ich przetwórstwo i dystrybucję, politykę rolną, wpływ rolnictwa na środowisko naturalne i globalne znaczenie rolnictwa (Frick i in., 1995). W 2003 roku D. L. Meischen i C. J. Trexler (2003) zaproponowali „zaktualizowaną” definicję świadomości na temat rolnictwa. Według ww. autorów podstawowa świadomość rolnicza powinna wykraczać poza znajomość ogólnych pojęć i procesów w rolnictwie przez jednostkę. Ich zdaniem szczególny nacisk powinien zostać położony na zdolność do osądów i zastosowania nabytej wiedzy do podejmowania osobistych decyzji przez konsumenta. Zdaniem K. Kovar i A. Ball (2013) zmiana definicji świadomości rolniczej była konieczna ponieważ postrzeganie rolnictwa pod koniec XX wieku, kiedy po raz pierwszy zdefiniowano to pojęcie, a w pierwszym dwudziestoleciu XXI wieku jest inne. Wynika to $\mathrm{z}$ nowych trendów i zmian w samym rolnictwie, takich jak: genetycznie modyfikowane organizmy, rolnictwo ekologiczne, produkcja etanolu, zarządzanie środowiskowe itp.

Świadomość na temat rolnictwa stosunkowo niedawno stała się przedmiotem badań naukowych. Badania w tym zakresie prowadzone są głównie w Stanach Zjednoczonych. W analizach tych można wyróżnić trzy kierunki badań: ocena aktualnego poziomu świadomości na temat rolnictwa, ocena programów nauczania w tym zakresie oraz badania dotyczące metodyki nauczania wiedzy o rolnictwie. W badaniach tych dominują prace 
z pierwszego z wyżej wymienionych obszarów. Według K. Kovar i A. Ball (2013) prawie $47 \%$ badań z zakresu świadomości na temat rolnictwa dotyczy właśnie określenia poziomu świadomości rolniczej obywateli. Podmiotem tych badań są różne grupy respondentów, wyodrębnione najczęściej na podstawie wieku: uczniowie szkół podstawowych, średnich, studenci, osoby dorosłe (Harris, Birkenholz, 1996; Wearly i in., 1999; Colbath, Morrish, 2010; Hess, Trexler, 2011).

Drugim obszarem badań są studia związane z oceną programów nauczania rolnictwa na różnych poziomach edukacji szkolnej. E. L. Rilla i in. (1991) na podstawie przeprowadzonych analiz określili 4 elementy skutecznego procesu nauczania $\mathrm{w}$ zakresie świadomości rolniczej: kompetentna i zaangażowana kadra nauczycielska, konieczność powiązania programu dotyczącego wiedzy o rolnictwie $\mathrm{z}$ ogólną podstawą programową oraz odpowiednie materiały wykorzystywane na zajęciach. Z kolei R. Mabie i M. Baker (1996) udowodnili zależność, że uczniowie zaangażowani w różne aktywności z tego zakresu tematycznego, jak np.: prowadzenie ogrodu szkolnego, opieka nad pisklętami, pieczenie chleba, osiagają znacznie lepsze wyniki w porównaniu $\mathrm{z}$ osobami, które nie uczestniczyły $\mathrm{w}$ takich zajęciach. $\mathrm{W}$ polskim systemie edukacji podstawowa wiedza o rolnictwie jest przekazywana uczniom szkół podstawowych, gimnazjów i liceów w ramach edukacji przyrodniczej (Podstawa..., 2012).

W obrębie świadomości rolniczej, najrzadziej prowadzone sa badania dotyczace metodyki nauczania wiedzy o rolnictwie. We wczesnych badaniach na ten temat naukowcy wyodrębnili 11 obszarów tematycznych związanych $\mathrm{z}$ rolnictwem, które uważali za niezbędne w programach nauczania uczniów i studentów. Obecnie za konieczne przyjmuje się 7 obszarów (znaczenie rolnictwa, polityka rolna, środowisko naturalne, produkcja roślinna i zwierzęca, przetwórstwo i marketing) (Birkenholtz, 1993).

Poziom świadomości rolniczej obywateli dotychczas w niewielkim stopniu został opisany w polskiej literaturze przedmiotu. W piśmiennictwie z tego zakresu tematycznego dominują prace dotyczące określenia poziomu specjalistycznej wiedzy rolniczej (Gołębiewska, Klepacki, 2005; Kołoszko-Chomentowska, 2008; Krzyworzeka, 2011; Kania, 2014). Drugą grupa prac są opracowania dotyczące określenia poziomu wiedzy społeczeństwa o zrównoważonym rozwoju rolnictwa i obszarów wiejskich (Kowalska i inni, 2008; Kondratowicz-Pozorska, 2015). Jednocześnie na rynku występuje szereg opracowań, których tematyka przynajmniej częściowo dotyczy problematyki świadomości rolniczej obywateli. Sa to prace traktujące o świadomości ekologicznej społeczeństwa (environmental awareness) (Tuszyńska 2013; Badanie..., 2014) czy świadomości żywieniowej konsumentów (food literacy) (Goryńska-Goldman, Ratajczak, 2010; Wilczyńska, Wittbrodt, 2012).

\section{Metody badawcze i źródła informacji}

Zasadniczym źródłem danych wykorzystanych do analizy i wnioskowania były informacje pierwotne uzyskane $\mathrm{z}$ badań własnych. Badania metodą PAPI przeprowadzono w okresie październik-listopad 2016 r., a wielkość próby badawczej wynosiła 436 osób. Wywiad został przeprowadzony $\mathrm{z}$ młodzieżą studiującą $\mathrm{w}$ uczelniach wyższych województwa małopolskiego (uniwersytetach, szkołach technicznych, rolniczych, szkołach ekonomicznych, pedagogicznych i pozostałych (teologicznych, aktorskich). Były to osoby kształcące się na pierwszym i drugim stopniu kierunków przyrodniczych $(31 \%)$, 
humanistycznych (30\%), technicznych (24\%) i pozostałych $(15 \%)$. W roku akademickim 2014/2015 liczba studentów w analizowanym województwie wynosiła 182597 osób (Szkoły..., 2015). W badaniach zastosowano celowy dobór próby. Do oszacowania minimalnej liczby próby, wykorzystano poniższy wzór (Szreder, 2004):

$$
n=\frac{\frac{1}{4} \cdot N}{N \cdot \frac{d^{2}}{z_{\alpha / 2}^{2}}+\frac{1}{4}}
$$

gdzie:

$\mathrm{N}$ - liczebność populacji,

d - błąd statystyczny,

$\mathrm{Z}_{\alpha} / 2$ - wartość zmiennej losowej $\mathrm{Z}$ o rozkładzie normalnym standaryzowanym.

W badaniach przyjęto, że maksymalny błąd statystyczny wyników może wynieść 5\%. Niezbędna, minimalna wielkość próby została ustalona na poziomie 433 osób. Badaniami objęto 450 studentów. Po odrzuceniu niespójnych i nieprawidłowo wypełnionych kwestionariuszy, dalszej analizie poddano dane z 436 formularzy.

Badana próba pod względem płci respondentów była identyczna jak w populacji generalnej. Wśród osób, które uczestniczyły w badaniu 59\% stanowiły kobiety, a 41\% mężczyźni (tab. 1). Prawie 55\% respondentów zamieszkiwało tereny wiejskie, pozostałe osoby były mieszkańcami miast. Niemal $15 \%$ badanej populacji wskazało, że mieszka w miastach powyżej 100000 mieszkańców. Wśród osób mieszkających na wsi, co drugi respondent mieszkał w gospodarstwie domowym rolników. Średni obszar gospodarstwa rolnego wynosił 7,6 ha. Najmniejsze gospodarstwo miało powierzchnię 1 ha, największe 70 ha. Prawie $2 / 3$ badanych osób wskazało, że posiada członków rodziny/znajomych, którzy utrzymują się $\mathrm{z}$ pracy $\mathrm{w}$ rolnictwie, $\mathrm{z}$ kolei $53 \%$ młodych osób zaznaczyło, że ich członkowie rodziny/znajomi pracują w pozostałych agregatach agrobiznesu.

Tabela 1. Struktura respondentów (\%)

Table 1 . The structure of the respondents (\%)

\begin{tabular}{ll|c}
\hline \multicolumn{2}{c|}{ Wyszczególnienie } & Udział w próbie badawczej (\%) \\
\hline \multirow{2}{*}{ Płeć } & Kobieta & 59 \\
& Mężczyzna & 41 \\
& Wieś & 55 \\
Miejsce zamieszkania & Miasto do 100 tys. mieszkańców & 31 \\
& Miasto powyżej 100 tys. mieszkańców & 14 \\
Respondent pracuje we własnym & Tak & 23 \\
gospodarstwie rolnym lub rodziców & Nie & 77 \\
Znajomi, którzy utrzymują się z pracy w & Tak & 67 \\
rolnictwie & Nie & 33 \\
Znajomi, którzy pracują w I (zaopatrzenie) & Tak & 46 \\
i III (przetwórstwo) agregacie agrobiznesu & Nie & 54 \\
\hline
\end{tabular}

Źródło: badania własne, $\mathrm{n}=436$. 
Do pomiaru i oceny świadomości młodzieży na temat rolnictwa wykorzystano indeks świadomości o rolnictwie (ISR). Budowę wskaźnika oparto na zasadach konstrukcji wskaźnika umożliwiającego ocenę poziomu świadomości rolniczej wg B. Birkenholz’a (1993). Zgodnie z tą metodologią świadomość na temat rolnictwa obejmuje podstawową wiedzę o rolnictwie oraz percepcję rolnictwa. Ogólny indeks ISR dotyczy siedmiu obszarów: znaczenia rolnictwa, polityki rolnej, wpływu rolnictwa na środowisko naturalne, informacji dotyczących produkcji roślinnej i zwierzęcej, przetwórstwa i marketingu żywności.

Zaproponowany przez B. Birkenholz'a (1993) formularz wywiadu umożliwia uwzględnienie różnic $\mathrm{w}$ funkcjonowaniu systemu agrobiznesu $\mathrm{w}$ różnych krajach. W wykorzystanym w badaniach kwestionariuszu treść wybranych pytań dostosowano do warunków Polski, np. przeciętną wielkość gospodarstwa rolnego w Polsce, odsetek osób zatrudnionych $w$ polskim rolnictwie czy udział rolnictwa w tworzeniu PKB. Kwestionariusz ten składał się $\mathrm{z}$ trzech części. W pierwszej części zamieszczono stwierdzenia, w przypadku których respondenci mogli udzielić odpowiedzi twierdzącej („tak”), nie zgodzić się ze stwierdzeniem (odpowiedź „nie”) lub zaznaczyć odpowiedź „nie wiem". W drugiej części do oceny stwierdzeń zastosowano pięciostopniową skalę Likerta. Ostatnią część stanowiła metryczka.

W pierwszej części zamieszczono 24 pytania. Poprawne odpowiedzi otrzymywały 1 punkt, natomiast odpowiedzi błędne, jak również odpowiedź „nie wiem”- 0 punktów. Minimalnie respondenci mogli w tej części uzyskać 0 punktów, a maksymalnie 24. W kolejnej części zamieszczono 18 stwierdzeń. Minimalna liczba punktów, którą badani mogli uzyskać w tej cześsi badania wynosiła 18 pkt., natomiast maksymalna - 90. Ogólny indeks świadomości rolniczej to suma wyników z obydwóch części. ISR przyjmuje zatem wartości z przedziału 18 - 114 punktów. Wysoki wynik wskazuje, że jednostka ma wysoki poziom świadomości rolniczej, ale niekoniecznie jest ekspertem w tej dziedzinie.

Analiza statystyczna badanego materiału obejmowała sumaryczne wskaźniki statystyczne (średnia arytmetyczna, odchylenie standardowe) oraz nieparametryczny test chi kwadrat $\left(\chi^{2}\right)$, pozwalający na ocenę istotności związku między zmiennymi, gdy przynajmniej jedna $z$ nich jest niemierzalna. Testowanie wszystkich hipotez zerowych prowadzono przy poziomie istotności $\alpha=0,05$. Poza źródłami pierwotnymi wykorzystano również źródła wtórne obejmujące zarówno krajową jak i zagraniczną literaturę. Wyniki $\mathrm{z}$ przeprowadzonej analizy przedstawiono $\mathrm{w}$ formie opisowej, tabelarycznej i graficznej.

\section{Poziom świadomości rolniczej młodzieży akademickiej - wyniki badań empirycznych}

Zgodnie z założeniami, elementem składającym się na ISR jest podstawowa wiedza o rolnictwie. Jak wynika $z$ danych zaprezentowanych w tabeli 2 , średnia wartość wskaźnika podstawowej wiedzy o rolnictwie dla badanej grupy wynosi 15,5 pkt. Żadna z osób biorących udział $\mathrm{w}$ badaniu nie udzieliła poprawnej odpowiedzi na wszystkie pytania. Wśród badanych nie było również studenta, który udzieliłby samych błędnych odpowiedzi. 
Tabela 2. Podstawowe statystyki dla wskaźnika świadomości rolniczej i jego elementów

Table 2. Basic statistics for the index of agricultural awareness and its components

\begin{tabular}{l|cccc}
\hline \multicolumn{1}{c|}{ Wyszczególnienie } & Średnia arytmetyczna & Odchylenie standardowe & Maksimum & Minimum \\
\hline Wiedza & 15,5 & 2,12 & 8 & 18 \\
Percepcja & 47,6 & 1,41 & 38 & 76 \\
Wskaźnik ogółem & 63,1 & 3,54 & 50 & 90 \\
\hline
\end{tabular}

Źródło: badania własne, $\mathrm{n}=436$.

W części dotyczącej ogólnej wiedzy o rolnictwie, niemal 2/3 odpowiedzi $(63 \%)$ zostało poprawnie udzielonych, odnotowana także niemal $20 \%$ błędnych odpowiedzi, a 18\% respondentów zaznaczyło odpowiedź „nie wiem” (tab. 3). Wyniki te korespondują z rezultatami badań innych autorów (Birkenholz, 1993). Grupa pytań dotycząca produkcji zwierzęcej charakteryzowała się najwyższym odsetkiem poprawnych odpowiedzi. Nieco ponad $90 \%$ osób znało odpowiedź na te pytania. Studenci nie mieli również większych problemów $\mathrm{z}$ odpowiedziami na pytania dotyczące produkcji roślinnej oraz znaczenia rolnictwa. Otrzymane rezultaty są zbieżne z wynikami innych badań. Jak wynika z sondażu przeprowadzonego na zlecenie Komisji Europejskiej ponad połowa młodych Europejczyków (do 24 roku życia) uważa, że rolnictwo i obszary wiejskie są bardzo ważne dla naszej przyszłości. Taką opinię najezęściej wyrażali respondenci ze Słowenii, Portugalii i Słowacji. Najniżej znaczenie rolnictwa ocenili studenci z Łotwy (Special..., 2016). $\mathrm{Z}$ kolei najmniej poprawnych odpowiedzi udzielono $\mathrm{w}$ przypadku pytań dotyczących wpływu rolnictwa na środowisko naturalne (43\% poprawnych odpowiedzi). Otrzymane wyniki potwierdzają rezultaty wcześniej prowadzonych badań, z których wynika, że polskie społeczeństwo charakteryzuje się niskim poziomem świadomości ekologicznej (Tuszyńska 2013; Badanie..., 2014), rozumianej jako: „stopień w jakim mieszkańcy interesują się środowiskiem naturalnym i jego ochroną" (Strategia..., 2013). Wyższym poziomem świadomości ekologicznej cechuje się młodzież z Austrii i Niemiec, natomiast najniższy poziomem wiedzy o środowisku zauważono wśród obywateli Grecji, Cypru, Rumunii i Bułgarii (Ruben, Blanco, 2010). Obszarami podstawowej wiedzy o rolnictwie, w których respondenci zaznaczyli najwięcej odpowiedzi „nie wiem” były marketing i polityka rolna. Wyniki te koresponduja z rezultatami analiz innych autorów. Jak wynika z badań prowadzonych $w$ ramach Eurobarometru (Special..., 2016), 47\% osób z grupy wiekowej do 24 roku życia nigdy nie słyszało o Wspólnej Polityce Rolnej. Najwyższym poziomem wiedzy w zakresie polityki rolnej cechowali się mieszkańcy Szwecji, Litwy i Finlandii, najniższym natomiast obywatele Włoch, Hiszpanii i Wielkiej Brytanii.

Drugim modułem indeksu świadomości rolniczej była percepcja rolnictwa. Respondenci w tej części mogli uzyskać minimalnie 18 punktów, a maksymalnie 90 punktów. Jak wynika z przeprowadzonych badań, przeciętna wartość wskaźnika percepcji dla badanej grupy wynosiła 47,6 pkt. Zakres odpowiedzi respondentów w tej części zawierał się w przedziale od 38 do 76 punktów (tab. 2). Porównując uzyskane wyniki $\mathrm{z}$ rezultatami badań przeprowadzonymi $\mathrm{w}$ innych krajach, można stwierdzić, że badana grupa młodzieży znaczenie rolnictwa ocenia znaczenie wyżej, od kolegów z innych krajów (Birkenholz, 1993). Jak twierdzi J. Wilkin (2013), wynika to z kilku faktów. Po pierwsze, znaczna część polskiego społeczeństwa posiada wiejskie korzenie. Po drugie, prawie $40 \%$ ludności Polski mieszka na wsi, a niemal 15\% zatrudnionych zaangażowanych jest w działalność rolniczą, dającą około 4\% PKB. 
Tabela 3. Odpowiedzi respondentów w module dotyczącym podstawowej wiedzy o rolnictwie (\%)

Table 3. The respondents' answers in the module concerning basic knowledge about agriculture (\%)

\begin{tabular}{c|ccc}
\hline Wyszczególnienie & $\begin{array}{c}\text { Odpowiedzi poprawne } \\
(\%)\end{array}$ & $\begin{array}{c}\text { Odpowiedzi błędne } \\
(\%)\end{array}$ & $\begin{array}{c}\text { Odpowiedź ,Nie wiem” } \\
(\%)\end{array}$ \\
\hline Znaczenie rolnictwa & 70 & 13 & 17 \\
Polityka rolna & 53 & 19 & 28 \\
Środowisko naturalne & 43 & 43 & 14 \\
Produkcja roślinna & 79 & 11 & 10 \\
Produkcja zwierzęca & 91 & 7 & 2 \\
Przetwórstwo & 48 & 26 & 26 \\
Marketing & 56 & 15 & 29 \\
Ogółem & 63 & 19 & 18 \\
\hline
\end{tabular}

Źródło: badania własne, $\mathrm{n}=436$.

Średnia wartość ogólnego wskaźnika świadomości rolniczej była na poziomie 63 punktów. Respondent o najniższym poziomie wiedzy na temat rolnictwa uzyskał 50 pkt., natomiast maksymalny wynik to 90 pkt. na 114 możliwych do uzyskania. W celu przeprowadzenia weryfikacji testem $\chi^{2}$, uzyskane wyniki zgrupowano $\mathrm{w}$ trzy przedziały: niski poziom świadomości rolniczej (50-63 pkt.), średni (64-77 pkt.) i wysoki (78-90 pkt). Jak wynika z przeprowadzonej analizy, prawie $70 \%$ respondentów charakteryzowało się niskim stopniem świadomości na temat rolnictwa, co piąty badany - średnim, a co dziesiąty - wysokim (rys. 1).

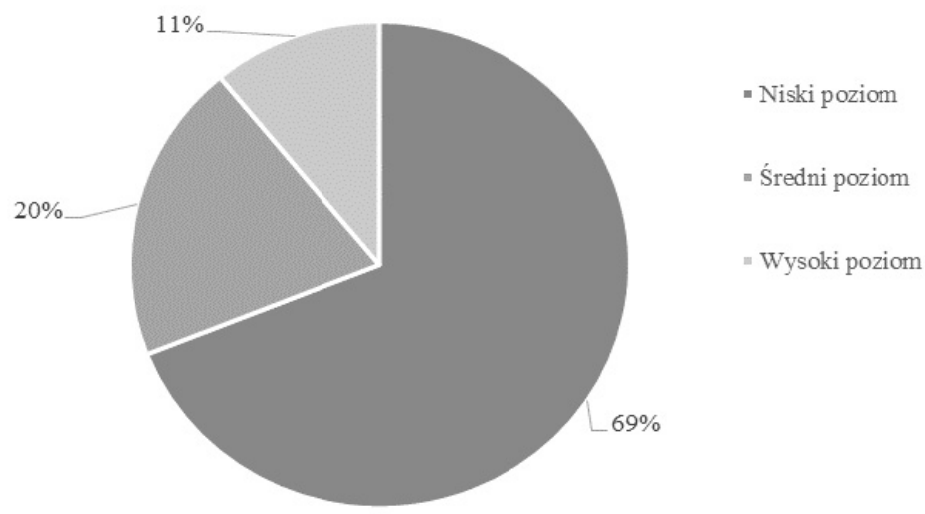

Rys. 1. Poziomy wskaźnika świadomości rolniczej w badanej grupie respondentów (\%)

Fig. 1. The levels of the indicator of rural awareness in the group of respondents under study (\%)

Źródło: badania własne, $n=436$. 
$\mathrm{Na}$ podstawie przeprowadzonej analizy można stwierdzić, że poziom wiedzy o rolnictwie jest zdeterminowany wieloma czynnikami, jednym z nich jest płeć (tab. 4).

Tabela 4. Struktura respondentów wg poziomów indeksu świadomości rolniczej (\%)

Table 4. The structure of respondents according to the levels of rural awareness index (\%)

\begin{tabular}{|c|c|c|c|c|}
\hline \multirow{2}{*}{\multicolumn{2}{|c|}{ Wyszczególnienie }} & \multicolumn{3}{|c|}{ Poziom wiedzy o rolnictwie } \\
\hline & & \multirow{2}{*}{$\frac{\text { Niski }}{79}$} & \multirow{2}{*}{$\frac{\text { Średni }}{7}$} & \multirow{2}{*}{$\frac{\text { Wysoki }}{0}$} \\
\hline Płeć & Kobieta & & & \\
\hline & Mężczyzna & 50 & 30 & 20 \\
\hline \multirow[t]{2}{*}{ Miejsce zamieszkania } & Wieś & 64 & 30 & 6 \\
\hline & Miasto & 72 & 5 & 3 \\
\hline \multirow[t]{2}{*}{ Gospodarstwo rolne } & Tak & 66 & 31 & 4 \\
\hline & $\mathrm{Nie}$ & 86 & 7 & 7 \\
\hline \multirow{2}{*}{$\begin{array}{l}\text { Znajomi, którzy utrzymują się z } \\
\text { pracy w gospodarstwie rolnym }\end{array}$} & Tak & 71 & 21 & 8 \\
\hline & $\mathrm{Nie}$ & 73 & 27 & 0 \\
\hline \multirow{2}{*}{$\begin{array}{l}\text { Znajomi, którzy pracują w } \\
\text { agrobiznesie }\end{array}$} & Tak & 80 & 15 & 5 \\
\hline & $\mathrm{Nie}$ & 65 & 30 & 5 \\
\hline
\end{tabular}

Źródło: badania własne, $\mathrm{n}=436$.

Kobiety charakteryzowały się niższym poziomem wiedzy o rolnictwie. Przeciętny wynik uzyskany w grupie respondentek to 60 punktów, natomiast w grupie respondentów 65. Prawie $80 \%$ kobiet charakteryzowała się niskim stopniem świadomości rolniczej, pozostałe respondentki (21\%) - średnim. Żadna z kobiet nie cechowała się wysokim poziomem wskaźnika. Z tego też względu w tym przypadku nie można było przeprowadzić weryfikacji testem niezależności $\chi^{2}$, ponieważ minimalna liczba odpowiedzi w komórkach tabeli kontyngencji powinna liczyć 8 obserwacji (Kukuła, 2012). Z kolei, co drugi mężczyzna charakteryzował się niskim poziomem świadomości na temat rolnictwa, co trzeci - średnim.

Następnym czynnikiem determinującym poziom świadomości o rolnictwie jest miejsce zamieszkania. Jak wynika z przeprowadzonych badań, wyższym poziomem świadomości rolniczej cechowali się mieszkańcy wsi. Przeciętna liczba punktów uzyskana przez tę grupę wynosiła 64 punkty. Mieszkańcy miast uzyskali wynik niższy o 5 pkt. Analiza testem niezależności $\chi^{2}$, wykazała, że istnieją statystycznie istotne różnice w poziomie świadomości rolniczej między mieszkańcami miast i wsi $\left(\chi^{2}=9,5 ; d f=2\right)$, co koresponduje z wynikami innych badaczy (Birkenholz, 1993; Special ..., 2016). Zarówno w przypadku respondentów z obszarów wiejskich, jak i mieszkańców miast, dominowały osoby $\mathrm{z}$ niskim poziomem świadomości rolniczej, jednak w przypadku respondentów z obszarów wiejskich zauważono wyższy udział osób cechujących się średnim i wysokim poziomem świadomości na temat rolnictwa.

Jak wynika $\mathrm{z}$ przeprowadzonej analizy statystycznej, poziom wiedzy o rolnictwie zależy także od faktu, czy osoba biorąca udział w badaniach lub jej rodzice prowadzili gospodarstwo rolne $\left(\chi^{2}=7,7 ; d f=2\right)$. Niskim poziomem wiedzy z omawianego zakresu tematycznego charakteryzowało się $2 / 3$ grupy respondentów posiadających gospodarstwa, nieco ponad $30 \%$ badanych z tej grupy uzyskało wynik średni, pozostałe osoby cechowały się najwyższym poziomem świadomości na temat rolnictwa. W przypadku osób nie 
związanych z prowadzeniem gospodarstw rolnych zdecydowana większość respondentów legitymowała się niskim poziomem świadomości rolniczej (86\%). Pozostali badani reprezentowali poziom średni lub wysoki (po 7\%).

Z kolei, fakt posiadania znajomych lub członków rodziny, którzy utrzymywali się z pracy w rolnictwie $\left(\chi^{2}=1,2, d f=2\right)$ lub byli zatrudnieni w pozostałych agregatach systemu agrobiznesu $\left(\chi^{2}=1,4, d f=2\right)$ nie wpływa na poziom świadomości rolniczej jednostki. Średnia liczba punków wskaźnika ISR, zarówno dla osób w przypadku których bliscy i znajomi byli zatrudnieni $\mathrm{w}$ jednym $\mathrm{z}$ agregatów systemu agrobiznesu (zaopatrzenie, rolnictwo, przetwórstwo i obrót), oraz dla respondentów nie posiadających takich znajomych wynosiła 62 pkt.

\section{Podsumowanie}

Przeprowadzone badania umożliwiły określenie poziomu świadomości rolniczej młodzieży akademickiej w województwie małopolskim, a także identyfikację wybranych czynników, które determinują ten poziom. W tym celu wykorzystano indeks świadomości rolniczej (ISR). Jak wynika z przeprowadzonych badań, większość młodzieży akademickiej nie rozumie roli rolnictwa, którą odgrywa ono w gospodarce, społeczeństwie i środowisku. Oznacza to, że sposób upowszechnia wiedzy o rolnictwie na kolejnych etapach edukacji szkolnej, jak również metody edukacji całego społeczeństwa w tym zakresie są mało efektywne i niewystarczające.

Czynnikami determinującymi poziom świadomości rolniczej w grupie młodzieży były płeć oraz miejsce zamieszkania. Wyższym poziomem świadomości rolniczej cechowali się mężczyźni oraz osoby zamieszkujące obszary wiejskie, a także respondenci pracujący w gospodarstwie rolnym. Nie stwierdzono natomiast związku pomiędzy poziomem świadomości rolniczej młodej osoby, a faktem zatrudnia rodziców/pozostałych członków rodziny w rolnictwie, a także pozostałych agregatach sektora agrobiznesu.

Obszarem tematycznym, który wymaga pilnych działań edukacyjnych jest problematyka dotycząca wpływu rolnictwa na środowisko naturalne. W tym przypadku respondenci zaznaczyli najwięcej błędnych odpowiedzi. Działań edukacyjnych wymagają również zagadnienia dotyczące marketingu żywności oraz polityki rolnej. W przypadku tych dwóch obszarów tematycznych, studenci najczęściej wskazywali odpowiedź „nie wiem".

Rozwój rolnictwa i obszarów wiejskich zależy $\mathrm{w}$ dużym stopniu od poziomu świadomości społeczeństwa na temat rolnictwa, dlatego badania w tym zakresie powinny być kontynuowane, a pozyskane informacje wykorzystane do opracowywania programów edukacyjnych $\mathrm{w}$ zakresie wiedzy o rolnictwie $\mathrm{w}$ szkołach oraz do planowania kampanii upowszechniających te wiedzę, nie tylko $\mathrm{w}$ grupie młodych osób, ale w całym społeczeństwie. 


\section{Literatura}

Badanie świadomości i zachowań ekologicznych mieszkańców Polski. (2014). Pobrane 31 stycznia 2017 z: https://www.mos.gov.pl/g2/big/2014 12/fe749deb7e1414bf1c4afbc6548300f9.pdf.

Birkenholtz, R.H. (1993). Pilot Study of Agricultural Literacy. Final Report. Pobrane 31 stycznia 2017 z: https://eric.ed.gov/?id=ED369890.

Colbath, S.A., Morrish, D.G. (2010). What do college freshmen know about agriculture? An evaluation of agricultural literacy. NACTA Journal, 54(3), 14-17.

Frick, M.J., Birkenholz, R.J., Machtmes, K. (1995). Rural and urban adult knowledge and perceptions of agriculture. Journal of Agricultural Education, 36(2), 44-53.

Gołębiewska, B., Klepacki, B. (2005). Wykształcenie rolników jako forma różnicująca sytuację gospodarstw rolnych. Nierówności Społeczne a Wzrost Gospodarczy, nr 7, 457-464.

Goryńska-Goldman, E., Ratajczak, P. (2010). Świadomość żywieniowa a zachowania żywieniowe konsumentów. Journal of Agribusiness and Rural Development, 4(18), 41-48.

Harris, C.R., Birkenholz, R.J. (1996). Agricultural literacy of Missouri secondary school educators. Journal of Agricultural Education, volume 37, number 2, 63-71. DOI: 10.5032/jae.1996.02063.

Hess, A.J., Trexler, C.J. (2011). A qualitative study of agricultural literacy in urban youth: Understanding for democratic participation in renewing the agri-food system. Journal of Agricultural Education, volume 52, number 2, 151-162. DOI: 10.5032/jae.2011.02151.

Kania, J. (2014). System wiedzy i informacji rolniczej w rolnictwie polskim. Prace Naukowe UE we Wroctawiu, $\mathrm{nr} 360,55-62$.

Kołoszko-Chomentowska, Z. (2008). Wykształcenie ludności rolniczej jako determinanta rozwoju rolnictwa. Zeszyty Naukowe SGGW Ekonomika i Organizacja Gospodarki Żywnościowej, nr 67, 79-86.

Kondratowicz-Pozorska, J. (2015). Wiedza społeczeństwa o roli rolników w kreowaniu zrównoważonego rozwoju (na przykładzie mieszkańców województwa zachodniopomorskiego). Roczniki Naukowe SERiA, tom XVII, zeszyt 3, 186-193.

Kovar, K., Ball, A. (2013). Two Decades of Agricultural Research: A Synthesis in the Literature. Journal of Agricultural Education, volume 54, number 1, 167-178. DOI: 10.5032/jae.2013.01167.

Kowalska, M., Niedziółka, A., Gorczyca, A., Ropek, D. (2008). Wiedza studentów agroturystyki UR w Krakowie o zrównoważonym rozwoju obszarów wiejskich. Infrastruktura i Ekologia Terenów Wiejskich, nr 2, 139-167.

Krzyworzeka, A. (2001). Funkcjonowanie wiedzy rolniczej. E-mentor nr 3(40). Pobrane 31 stycznia 2017 z http://www.e-mentor.edu.pl/artykul/index/numer/40/id/848.

Kukuła, K. (2012). Elementy statystyki w zadaniach. Warszawa: Wydawnictwo Naukowe PWN.

Mabie, R., Baker, M. (1996). The influence of experimental instruction on Urban elementary students' knowledge of the food and fiber system. Journal of Extension, 34(6). Pobrane 31 stycznia 2017 z: www.jeo.org.

Meischen, D.L., Trexler, C.J. (2003). Rural elementary students' understanding of science and agricultural education benchmarks related to meat and livestock. Journal of Agricultural Education, 44(1), 43-55. DOI: $10.5032 /$ jae.2003.01043.

Piwowar, A. (2014). Drugi agregat agrobiznesu - rolnictwo. W: S. Urban (red.) Agrobiznes i biobiznes. Teoria i praktyka (s. 33-45). Wrocław: Wydawnictwo Uniwersytetu Ekonomicznego we Wrocławiu.

Podstawa programowa z komentarzem. Tom 5. Edukacja przyrodnicza w szkole podstawowej, gimnazjum i liceum. (2012). Pobrane 31 stycznia 2017 z: www.reformaprogramowa.gov.pl

Rilla, E.L., Desmond, D.J., Braverman, M.T., Ponzio, R.C., Lee, F., Sandlin, E., Kaney, C. (1991). Snapshots of current agricultural literacy programs. California Agriculture, 45(6), 6-7. DOI: 10.3733/ca.v045n06p6.

Ruben, M., Blanco, A. (2010). Environmental awareness and paper recycling. Cellulose Chemistry and Technology 44(10), 431-449

Special Eurobarometer 440. (2016). Europeans, Agriculture and the CAP. Report. Pobrane 30 kwietnia 2017 z: www.ec.europa.eu/COMMFrontOffice/publicopinion/index.../69759

Strategia Edukacji Ekologicznej Narodowego Funduszu Ochrony Środowiska i Gospodarki Wodnej na lata 20132016 z perspektywą do 2020 roku. (2013). Warszawa: Narodowy Fundusz Ochrony Środowiska i Gospodarki Wodnej.

Szkoły wyższe w województwie małopolskim w roku akademickim 2014/2015. (2015). Opracowanie sygnalne $\mathrm{Nr}$ 10, Kraków: Urząd Statystyczne w Krakowie.

Szreder, M. (2004). Metody i techniki sondażowych badań opinii. Warszawa: Polskie Wydawnictwo Ekonomiczne.

Tuszyńska, L. (2013). Świadomość ekologiczna społeczności lokalnych. Oczekiwania a rzeczywistość. Rocznik Świętokrzyski, Ser. B-Nauki Przyr. 34, 149-160. 
Urban, S. (2014). Wstęp. W: S. Urban (red.) Agrobiznes i biobiznes. Teoria i praktyka (s. 11). Wrocław: Wydawnictwo Uniwersytetu Ekonomicznego we Wrocławiu.

Van Huylenbroeck, G., Vandermeulen, V., Mettepenningen, E., Verspecht, A. (2007). Multifunctionality of agriculture: A review of definitions, evidence and instruments. Living Reviews in Landscape Research, no. 3. Pobrane 31 stycznia 2017 z: http://www.livingreviews.org/lrlr-2007-3.

Wearly, M., Frick, M.J., Shelhamer, C.V. (1999). Montana legislators' knowledge and perception of agriculture. NACTA Journal, 43(1), 31-37.

Wilczyńska, A., Wittbrodt, M. (2012). Wiedza młodzieży akademickiej o żywności genetycznie modyfikowanej i jej postawy wobec tego zagadnienia. Zeszyty Naukowe Akademii Morskiej w Gdyni, Nr 73, 16-22.

Wilkin, J. (2013). Rolnictwo - funkcje teraz i w przyszłości. Pomorski Przegląd Gospodarczy. Pobrane 31 stycznia 2017 z: http://ppg.ibngr.pl/pomorski-przeglad-gospodarczy/rolnictwo-funkcje-teraz-i-w-przyszlosci

Williams, D.L. (1991). Focusing agricultural education research: Strategies for the professor. Journal of Agricultural Education, 32(3), 17-22. DOI: 10.5032/jae.1991.03017. 